\title{
SKRINING STATUS GIZI ANAK USIA SEKOLAH DASAR KOMUNITAS SUKU ANAK DALAM DI DESA NYOGAN, MUARO JAMBI
}

\author{
Anggelia Puspasari, Amelia Dwi Fitri, Nyimas Natasha Ayu Shafira \\ Fakultas kedokteran dan IImu Kesehatan Universitas Jambi \\ Corresponding author email: anggelia.puspasari@unja.ac.id
}

\begin{abstract}
Nutritional status in primary school children describe under five nutritional status and affected nutritional status in teenager, which second growth spurt happened. Early nutritional intervention due to malnourished was urge, this intervention may held in which nutritional status data was available. Suku Anak Dalam (SAD) was native tribe which catchup modernization in between conserve their native culture. Previous study in under five children reported this population have higher risk of stunting, the prevalence more than $40 \%$. The nutritional status data in this population not yet available. This study aims was to screen nutritional status in SAD primary school children. As much 31 children of SAD were participated in this study, demographic data and anthropometric data was taken. Nutritional status was determined CDC growth curve reference for children 2-18 years old. This study reported prevalence of stunting was $35,48 \%$, prevalence of undernutrition was $29,03 \%$ and prevalence of obesity and overweight was $16,13 \%$. Further study to analyzed factor related to this nutritional problem was needed, for better management of nutritional problem in this community.
\end{abstract}

Keyword: Nutritional status, Suku anak dalam, stunting, underweight, obesity, overweight

\begin{abstract}
Abstrak
Status gizi pada anak usia sekolah dasar status gizi pada usia ini dipengaruhi oleh status gizi saat balita dan akan mempengaruhi status gizi saat remaja, usia dimana lonjak tumbuh terjadi. Intervensi dini malnutrisi penting dilakukan apabila dijumpai masalah gizi, hal ini dapat dilakukan apabila data skrining status gizi tersedia. Suku Anak Dalam (SAD) adalah suku asli jambi yang mengejar modernisasi seraya melestarikan budaya asli mereka. Penelitian sebelumnya pada balita melaporkan populasi ini memiliki risiko stunting yang lebih tinggi, dengan prevalensi lebih dari 40\%. Data status gizi pada pada anak usia sekolah dasar populasi ini belum tersedia. Penelitian ini bertujuan untuk skrining status gizi pada anak SD SAD. Sebanyak 31 anak SAD ikut serta dalam penelitian ini. Dilakukan pengumpulan data demografi dan data antropometri. Status gizi ditentukan dengan acuan kurva pertumbuhan CDC untuk anak usia 2-18 tahun. Gambaran status gizi berdasarakan TB/U menunjukkan presentase anak dengan perawakan pendek sebanyak 35, 48\%. Gambaran status gizi berdasarkan IMT/U menunjukkan masalah gizi ganda. Persentase anak dengan gizi berlebih sebanyak $16,13 \%$ dan gizi kurang sebanyak $29,03 \%$.
\end{abstract}

Kata kunci: status gizi, suku anak dalam, stunting, gizi kurang, gizi lebih, obesitas

\section{PENDAHULUAN}

Peningkatan derajat kesehatan merupakan investasi bagi terwujudnya sumberdaya manusia yang produktif secara sosial dan ekonomi. Kecukupan gizi yang optimal merupakan salah satu modal penting untuk membangun sumber daya yang sehat. 
Kecukupan gizi ini harus dimulai sejak masa bayi dalam kandungan sampai masa perkembangan anak, remaja dan dewasa. Ada banyak faktor yang mempengaruhi kecukupan gizi anak, antara lain faktor sosio ekonomi orang tua, tidak semua anak mendapatkan gizi yang seimbang dikarenakan keterbatasan penyediaan pangan yang sehat dan bergizi. ${ }^{1}$ Oleh karena itu skrining gizi pada anak-anak dengan lingkungan yang "kurang beruntung" merupakan hal yang perlu dilakukan.

Siswa sekolah dasar berada pada rentang usia 6-12 tahun, usia persiapan menuju "growth spurt" kedua. Status gizi pada usia ini dipengaruhi oleh status gizi saat balita dan akan mempengaruhi status gizi saat remaja, sehingga skrining status gizi pada usia ini menjadi penting. Data dasar status gizi ini dapat digunakan untuk intervensi gizi yang dibutuhkan .2,3,4

Provinsi Jambi merupakan salah satu wilayan di Indonesia yang masih masih memiki berbagai permasalahan terkait status gizi. Data RISKESDAS 2018 menunjukkan berbagai permasalah status gizi seperti gizi buruk, perawakan sangat pendek (stunting), sangat kurus (underweight) maupun gemuk (obesitas) masih terjadi. Perluasan jangkauan pelayanan kesehatan, pemberdayaan masyarakat merupakan upaya yang harus terus ditingkatkan .5 Salah satu wilayah di Jambi yang memiliki potensi kurang gizi anak adalah pada komunitas Suku Anak Dalam (SAD).
Meskipun saat ini arus modernisasi telah menjangkau komunitas SAD. Akses pendidikan dan kesehatan terus dibangun akan tetapi sebagian besar kehidupan mereka masih dilaksanakan sebagaimana nenek moyang mereka hidup. ${ }^{6}$ Mulai dari aspek higienitas, pola dan kebiasaan makan memungkinkan prevalensi masalah gizi cukup tinggi pada komunitas SAD. Penelitian terdahulu menunjukkan prevalensi stunting dan underweight pada balita komunitas SAD di desa Nyogan lebih tinggi dari prevalensi Kabupaten Muaro Jambi, Provinsi Jambi maupun rerata nasional Indonesia. ${ }^{7}$ Sejauh studi literatur yang dilakukan penulis data status gizi pada anak usia sekolah pada komunitas SAD belum pernah dipublikasikan.

Beranjak dari hal tersebut, penelitian ini mengangkat masalah bagaimana gambaran status gizi anak usia sekolah dasar pada komunitas SAD di desa Nyogan, Kabupaten Muaro Jambi. Sehingga ketersediaan data dasar status gizi yang diperoleh diharapkan dapat digunakan untuk intervensi lebih lanjut permasalahan status gizi.

\section{METODE}

Skrining status gizi dilaksanakan di Sekolah dasar negeri 238 yang terletak didesa Nyogan. Sebanyak 31 anak usia sekolah dasar berusia 6-13 tahun mengikuti penelitian ini. Data usia diambil berdasarkan data dari sekolah.

Pengukuran berat badan menggunakan timbangan berat badan 
sedangkan pengukuran tinggi badan menggunakan stadiometer dengan kaidah antropometri baku. Satuan berat badan dalam kilogram dan tinggi badan dalam centimeter, tanpa desimal. Indeks massa tubuh (IMT) dihitung berdasarkan berat badan dalam kilogram dibagi tinggi badan kuadrat dalam meter.

Penentuan status gizi berdasarkan kurva referensi dari centre of the diseases (CDC) 2000 untuk anak usia 2-20 tahun sesuai anjuran Ikatan Dokter Anak Indonesia (IDAI). Kurva tinggi badan sesuai usia (TB/U) digunakan untuk menentukan permasalahan perawakan sangat pendek. Perawakan sangat pendek didefinisikan TB/U kurang dari persentil 5 kurva referensi CDC. Kurva IMT/U digunakan untuk menentukan permaslahan underweight, overweight dan obesitas. Underweight didefinisikan IMT/U kurang dari persentil 5 kurva referensi CDC. Overrweight didefinisikan IMT/U berada pada persentil 8595 kurva referensi CDC. Obesitas didefinisikan IMT/U berada diatas persentil 95 kurva referensi CDC. Tabel distribusi frekuensi digunakan untuk menampilkan data status gizi.

\section{HASIL DAN PEMBAHASAN}

Kegiatan skrining status gizi diikuti oleh 31 anak usia sekolah dasar di desa Nyogan yang duduk dikelas 1 hingga kelas 6 . Peserta perempuan hampir sama banyak dengan peserta laki-laki. Karakteristik peserta skrining tertera pada tabel 1 .
Tabel 1. Karakteristik Peserta

\begin{tabular}{ll}
\hline Karakteristik peserta & Data \\
\hline Usia, tahun & 9.19 \\
(mean, min-max) & $(6-13)$ \\
\hline Jenis kelamin & \\
Perempuan, N & 15 \\
Laki-laki, N & 16 \\
\hline Berat badan, kg & 27.16 \\
(mean, min-max) & $(14-46)$ \\
\hline Tinggi badan, cm & 125.82 \\
(mean, min-max) & $(105-148)$ \\
\hline IMT & 16.97 \\
(mean, min-max) & $(10.96-26.21)$ \\
\hline
\end{tabular}

Rerata berat badan peserta skrining $27,16 \mathrm{~kg}$. Berat badan paling rendah $14 \mathrm{~kg}$ dan paling berat $46 \mathrm{~kg}$. Tinggi badan rerata peserta skrining $125.82 \mathrm{~cm}$. Tinggi badan paling rendah $105 \mathrm{~cm}$ dan paling tinggi 148 cm. Rerata IMT 16.97. Nilai IMT paling rendah 10.96 dan IMT paling tinggi 26.21 (Tabel 1).

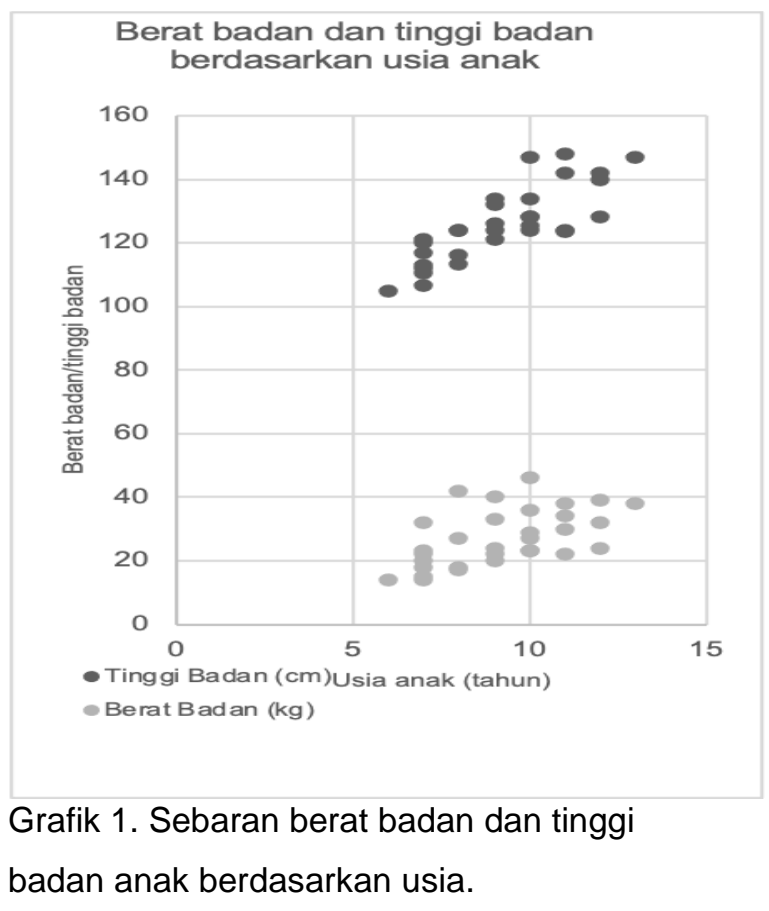


Sebaran berat badan dan tinggi badan anak berdasarkan kelompok usia ditampilkan pada grafik 1. Berat badan paling rendah berada pada kelompok usia 7 tahun, sedangkan berat badan paling berat berada pada usia 10 tahun. Tinggi badan paling tinggi berada pada kelompok usia 6 tahun, sedangkan tinggi badan paling tinggi berada pada usia 11 tahun.

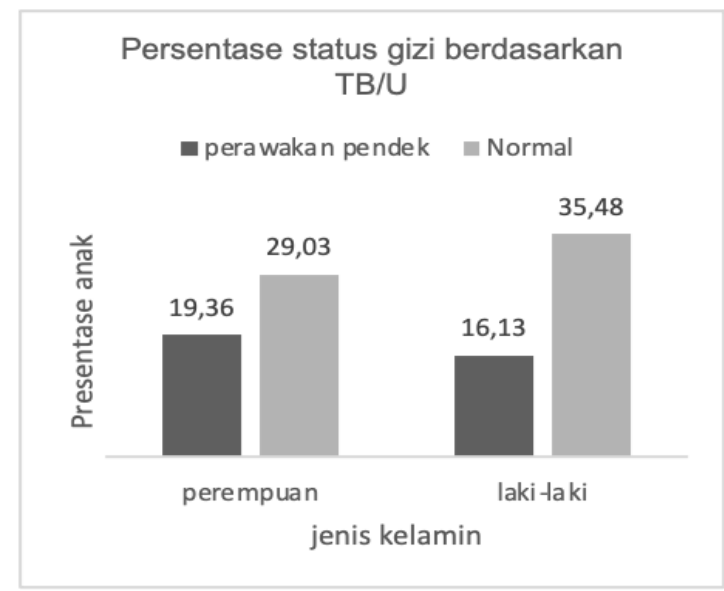

Grafik 2. Status gizi anak berdasarkan tinggi badan sesuai usia.

Penentuan gambaran status gizi berdasarkan tinggi badan sesuai usia digunakan kurva referensi CDC. Diperoleh hasil perawakan pendek sebanyak 16,13\% untuk anak perempuan dan 19,36\% untuk anak laki-laki (Grafik 2). Total anak dengan perawakan pendek sebanyak $35,49 \%$.

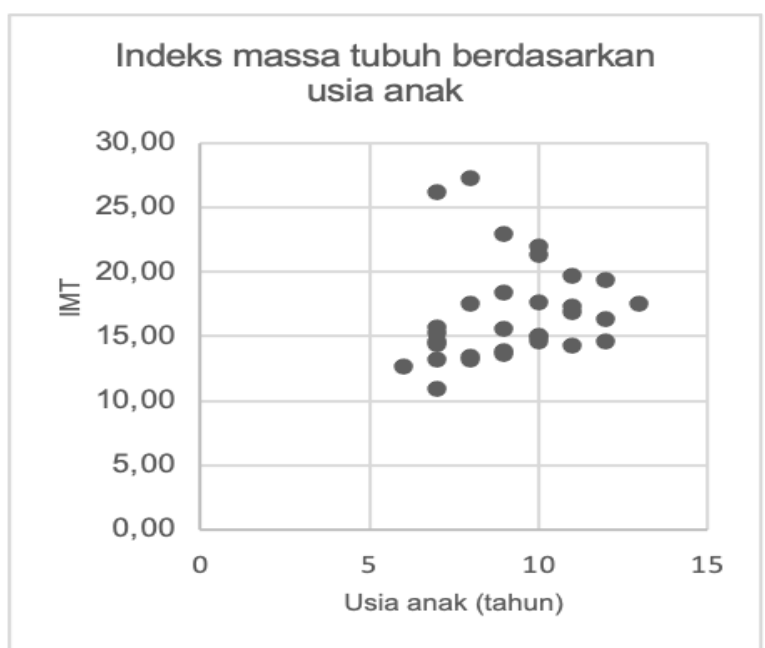

Grafik 3. Indeks massa tubuh berdasarkan usia anak.

Sebaran indeks massa tubuh anak berdasarkan usia ditampilkan pada grafik 3 . Nilai IMT tidak berbading lurus dengan usia. Nilai IMT tertinggi didapatkan pada kelompok usia 8 tahun.

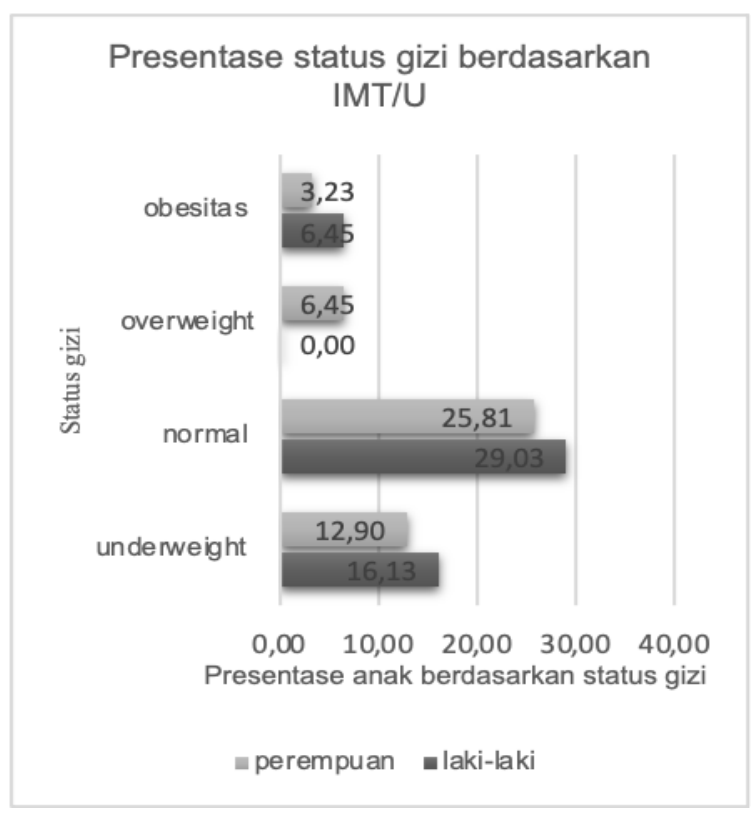

Grafik 4. Status gizi anak berdasarkan indeks massa tubuh sesuai usia. 
Gambaran status gizi berdasarkan IMT sesuai usia digunakan untuk melihat obesitas dan underweight. Kurva referensi CDC tahun 2000 digunakan sebagai acuan. Gambaran status gizi berdasarkan IMT/U ditampilkan pada tabel 4 . Sebanyak 5 orang yang mengalami gizi kurang (underweight) atau $29,03 \%$. Sebanyak $54,84 \%$ anak memiliki status gizi normal dan sebanyak $(16,13 \%)$ mengalami gizi lebih baik anak obesitas maupun overweight.

Hasil skrining status gizi pada anak usia sekolah dasar dikomunitas SAD yang bermukin di Desa Nyogan kabupaten Muaro Jambi menunjukkan permasalahan gizi ganda baik kelebihan gizi dan gizi kurang (Grafik 4). Lebih lanjut juga didapatkan permasalah gizi kronik berupa perawakan pendek atau yang dikenal sebagai stunting (Grafik 3).

Referensi data mengenai status gizi anak usia sekolah dasar pada komunitas SAD sejauh pencarian kepustakaan oleh penulis tidak ditemukan. Penelitian terdahulu melaporkan, prevalensi stunting balita SAD sebesar $42,2 \%{ }^{7} \quad$ Berdasarkan kriteria epidemiologi, kelompok usia balita SAD memiliki risiko stunting sangat tinggi. Hal tersebut ditandai dengan prevalensi stunting pada balita $>40 \% .^{8}$

Tatalaksana masalah gizi pada balita yang tidak adekuat dapat menyebabkan masalah gizi tersebut berlanjut hingga usia sekolah dasar. Hal tersebut sejalan dengan penelitian ini yang melaporkan prevalensi stunting sebesar $35,49 \%$ pada anak usia sekolah SAD. Kelompok usia sekolah dasar SAD memiliki risiko tinggi stunting, prevalensi stunting $>30 \% .^{8}$ Secara nasional meskipun prevalensi stunting pada anak usia sekolah dasar menurun dari $35,4 \%$ (risiko tinggi) ditahun 2013 menjadi 20,6\% ditahun 2018, akan tetapi masih belum dapat memenuhi target $\mathrm{WHO}$ prevalensi stunting $<20 \% .5$

Penelitian terdahulu melaporkan Jumlah anggota keluarga yang besar, rendahnya pendidikan ibu maupun kepala keluarga meningkatkan risiko kejadian stunting pada anak usia sekolah dasar di Indonesia. $^{9}$ Sejalan dengan hal tersebut penelitan pada balita SAD melaporkan determinasi kejadian stunting pada balita disebabkan antara lain oleh pemberian ASI yang tidak adekuat dan jumlah anggota keluarga yang besar. ${ }^{7}$

Penelitian epidemiologi di Indonesia menunjukkan permasalah gizi ganda tidak hanya terjadi didaerah perkotaan, daerah pedesaan atau penyangga kota juga mengalami masalah yang sama. Meskipun presentasi gizi lebih (obesitas dan overweight) lebih banyak diarea perkotaan sedangkan masalah gizi kurang (underweight) lebih banyak diarea pedesaan. ${ }^{10} \mathrm{Hal}$ yang sama juga dilaporkan pada penelitian ini.

Hasil penelitian ini baru merupakan gambaran umum mengenai status gizi anak di komunitas SAD, berbagai studi lanjut masih diperlukan, antara lain studi kualitatif mengenai pola kebiasaan makan dan faktor- 
faktor yang menjadi barrier dalam

pemenuhan gizi seimbang di komunitas ini.

\section{KESIMPULAN}

1. Gambaran status gizi berdasarakan $T B / U$ menunjukkan presentase anak dengan perawakan pendek sebanyak $35,48 \%$.
2. Gambaran status gizi berdasarkan IMT/U menunjukkan masalah gizi ganda. Persentase anak dengan gizi berlebih sebanyak $16,13 \%$ dan gizi kurang sebanyak 29,03\%

\section{DAFTAR PUSTAKA}

1. Kementrian kesehatan RI, 2015. Rencana Strategis kementrian Kesehatan Tahun 2015-2019. Kementerian kesehatan republik indonesia Sekolah Dasar di Kecamatan Rajeg Tangerang. Indonesian Journal of Human Nutrition. 1 (2): 135-148.

2. Mutiara H, Apriliana E, Suwandi JF, Utami N, 2019. Screening Pertumbuhan Anak, Edukasi tentang Stunting serta Pelatihan Pemantauan Pertumbuhan Anak pada Orang Tua Siswa Sekolah Dasar Negeri di Provinsi Lampung dalam Upaya Meningkatkan Derajat Kesehatan Anak Indonesia. JPM Ruwa Jurai. 4 (1): 36-41.

3. Palupi KC, Sa'pang M, Swasmilaksmita PD, 2018. Edukasi Gizi Seimbang pada Anak Sekolah Dasar di Kecamatan Cilincing Jakarta Utara. Jurnal Abdimas. 5 (1): 49-53.

4. Arfines PP, Puspitasari FD, 2017. Hubungan Stunting dengan Prestasi Belajar Anak Sekolah Dasar di Daerah Kumuh, Kotamadya Jakarta Pusat. Buletin Penelitian Kesehatan. 45 (1) 45-52.

5. Kementrian kesehatan RI Badan Penelitian dan Pengembangan Kesehatan, 2019. Hasil Utama Riset Kesehatan Dasar 2018.

6. Kurniawan D, Syafri RA, 2018. Besale Sebagai Kearifan Lokal suku anak Dalam di Desa Nyogan Kecamatan Mestong Kabupaten Muaro Jambi, Jambi. Seminar Nasional Manajemen dan bisnis ke-3, Program Studi Manajemen Fakultas Ekonomi dan Bisnis Universitas Jember

7. Haris A, Fitri A, Kalsum U, 2019. Determinan Kejadian Stunting dan Underweight pada Balita Suku Anak Dalam di Desa Nyogan Kabupaten Muaro Jambi Tahun 2019. Jurnal Kesmas Jambi. 3(1):41-53.

8. Gorstein J, Sullivan K, Yip R, Onis M De, Trowbridge F, Fajans P, Clugston G, 1994. Issues in the assessment of nutritional status using anthropometry. Bulletin of world health organization. 72(8):273-83.

9. Salimar, Kartono D, Fuada N, Setyawati B, 2013. Stunting anak usia sekolah di Indonesia menurut karakteristik keluarga. Penelitian gizi dan makanan. 36(2):121-6.

10. Rachmi CN, Agho KE, Li M, Baur LA, 2016. Stunting, Underweight and Overweight in Children Aged 2.04.9 Years in Indonesia: Prevalence Trends and Associated Risk Factors. Plos One. DOI:10.1371/journal.pone.0154756. 